\title{
Motivasi Peserta Didik Mengikuti Pembelajaran PJOK di Masa Pandemi Covid-19
}

\author{
Putu Agus Widiutama ${ }^{1 *}$, I.Pt.Panca Adi ${ }^{2}$, I.K. Semarayasa ${ }^{3}$ iD \\ ${ }^{123}$ Universitas Pendidikan Ganesha \\ *Corresponding author: aguswidiutama02@gmail.com
}

\begin{abstract}
Abstrak
Efek pandemi yang terjadi sekarang ini menyebabkan motivasi siswa untuk mengikuti pembelajaran PJOK semakin rendah. Selain itu kurangnya pengawasan saat pembelajaran daring menyebabkan siswa tidak sungguh-sungguh saat belajar. Tujuan penelitian ini adalah untuk mengetahui motivasi peserta didik kelas dalam mengikuti pembelajaran PJOK pada masa Pandemi Covid-19. Penelitian ini adalah penelitian deskriptif kuantitatif dengan jenis penelitian survei. Populasi penelitian adalah peserta didik dengan jumlah keseluruhan 237 orang. Sampel penelitian ini menggunakan non random sampling yaitu quota sampling dengan besaran $25 \%$ dari total populasi sehingga jumlah sampel dalam penelitian ini adalah 59. Data dianalisis menggunakan statistik deskritif kuantitatif dengan kategori interval. Hasil analisis menunjukkan bahwa data pada motivasi intrinsik memperoleh skor 88,1 jika dikonversikan ke dalam interval kategori termasuk dalam kategori sangat tinggi. Sedangkan pada motivasi ekstrinsik memperoleh skor 83,6 jika dikonversikan ke dalam interval kategori termasuk dalam kategori sangat tinggi. Dari kedua indikator pada faktor motivasi memperoleh skor 83.6. Jika dikonversikan ke dalam interval kategori, termasuk dalam kategori sangat tinggi. Kesimpulan dalam penelitian ini adalah terdapat peserta didik memiliki motivasi intrinsik dan ekstrinsik dalam pembelajaran PJOK pada masa pandemi covid-19.
\end{abstract}

Kata Kunci: Motivasi, Pembelajaran PJOK, Pandemi covid-19

\section{Abstract}

The current pandemic effect causes students' motivation to take PJOK learning to be lower. In addition, the lack of supervision during online learning causes students not to be serious when learning. This study aimed to determine the motivation of class students in participating in PJOK learning during the Covid-19 Pandemic. This research is quantitative descriptive research with the type of survey research. The research population is students with a total of 237 students. The sample of this study used non-random sampling, namely quota sampling with a size of $25 \%$ of the total population, so that the number of samples in this study was 59. Data were analyzed using quantitative descriptive statistics with interval categories. The analysis results showed that the data on intrinsic motivation obtained a score of 88.1 if it was converted into a category interval included in the very high category. While the extrinsic motivation obtained a score of 83.6 if converted into a category interval included in the very high category. From the two indicators on the motivation factor, it obtained a score of 83.6. If it is converted into a category interval, it is included in the very high category. This study concludes that there are students who have intrinsic and extrinsic motivation in learning PJOK during the covid-19 pandemic

Keywords: Motivation, Physical Education learning, Covid-19 pandemic

$\begin{array}{ll}\text { History: } & \text { Publisher: Undiksha Press } \\ \text { Received: } 03 \text { Oktober } 2021 & \text { Licensed: This work is licensed under } \\ \text { Revised: } 29 \text { Oktober } 2021 & \text { a Creative Commons Attribution 3.0 License } \\ \text { Accepted: } 01 \text { November } 2021 & \text { Published: } 25 \text { November } 2021\end{array}$




\section{Pendahuluan}

Kasus Covid-19 sudah tidak asing lagi untuk didengar, semua negara sudah mengetahuinya. Coronavirus (Covid-19) adalah kumpulan virus yang bisa menginfeksi sistem pernapasan (Pragholapati, 2020). Pada banyak kasus, virus ini hanya menyebabkan infeksi pernapasan ringan, seperti flu. Namun, virus ini juga bisa menyebabkan infeksi pernapasan berat, seperti infeksi paru-paru (pneumonia). Virus ini begitu cepat penyebaranya khususnya bagi orang yang sudah mempunyai penyakit bawaan dari lahir dan itu mempermudah virus untuk masuk kedalam tubuh apabila tidak melakukan prilaku hidup sehat. Dengan kondisi saat ini yang mengharuskan masyarakat di seluruh Indonesia menerapkan social distancing dan physical distancing karena mewabahnya virus Covid-19 membuat lembaga pendidikan termasuk sekolah-sekolah yang ada di Indonesia melakukan pembelajaran daring dari rumah untuk menekan angka penyebaran virus Covid-19 pada anak. Pembelajaran merupakan hal yang tidak dapat dipisahkan dari sebuah pendidikan formal karena pembelajaran merupakan suatu proses untuk membantu peserta didik agar dapat belajar dengan baik. Pembelajaran adalah kegiatan guru secara terprogram dalam desain intruksional, untuk membuat peserta didik belajar secara aktif, dan menekankan pada penyediaan sumber belajar ( Asyafah, 2019; Dimyati dan Mudjiono, 2006; Trianto, 2009) Pembelajaran dimasa pandemi covid 19 ini dapat dilakukan dengan menggunakan berbagai cara yang utamanya dilakukan dalam bentuk online atau daring, namn dalam pembelajaran tersebut perlu dibutuhkan motivasi yang lebih tinggi diberikan oleh guru (Wicaksono et al., 2021; Handarini \& Wulandari, 2020)

Pada dasarnya, metode pembelajaran daring tidak menuntut peserta didik untuk hadir di kelas. Peserta didik dapat mengakses pembelajaran melalui media internet. Penggunaan teknologi yang tersedia disekitar apabila diimbangi dengan diskusi dan panduan maka akan menjadi alat pengembangan keerampilan berpikir tingkat tinggi (Lashley, 2014). Data hasil survey yang dilakukan oleh Asosiasi Penyelenggara Jaringan Internet Indonesia (APJII) tahun 2016 menunjukkan pelajar di urutan kedua tertinggi dengan presentase 69,8\%, Setelah mahasiswa di urutan pertama dengan presentase $89,7 \%$. Namun sayangnya, di Indonesia akses internet para pelajar terhadap laman pendidikan masih belum optimal dalam penggunaannya sehingga hal tersebut perlu disikapi oleh para pendidik dan para peserta didiknya untuk lebih menggunakan internet dalam ranah pembelajaran, E-learning berperan untuk melengkapi kelas konvensional (secara tatap muka) bukan menggantikan kelas konvensional Shank dalam (Saifuddin, 2017). Sehingga mau tidak mau semua lembaga pendidikan harus mampu beradaptasi dengan baik dan terus mencari inovasi dalam penggunaan e-learning atau pembelajaran daring ini agar penggunaannya dapat lebih optimal dalam mencapai tujuan pembelajaran.

Motivasi peserta didik dalam mengikuti pembelajarn sangat diperlukan. Motivasi merupakan suatu kondisi yang menyebabkan atau menimbukan perilaku tertentu dan memberi arah dan ketahanan pada tingkah laku tersebut Wlodkowsky (dalam Sugiharto dkk, 2007:78). Motivasi merupakan suatu kekuatan atau tenaga pendorong untuk melakukan sesuatu hal atau menampilkan sesuatu perilaku tertentu (Gunarsa, 2008). Motivasi mempersoalkan bagai mana cara mengarahkan daya potensi bawahan, agar mau bekerja sama produktif berhasil mencapai dan mewujudkan tujuan yang telah ditentukan (Hasibuan, 2010). Motivasi sebagai bentuk minat yang muncul dalam diri seseorang karena adanya suatu dorongan atau stimulasi yang mengunggah dalam jiwanya. Penemuan-penemuan penelitian menunjukkan bahwa dorongan dari orang orang yang dekat dengannya akan mampu membuat motivasi bertambah. Motivasi adalah proses membangkitkan, mengarahkan, dan memantapkan prilaku arah satu tujuan Greenberg dalam (Djaali, 2007). Motivasi dikaitkan dengan dalam pembahasannya, sebagaimana dengan intelegensi dan bakat, maka minat dan motivasi adalah dua aspek psikis yang besar pengaruhnya terhadap pencapain keberhasilan. 
Motivasi merupakan daya penggerak atau pendorong untuk melakukan sesuatu pekerjaan yang bisa berasal dari dalam diri dan juga dari luar. Maka dari itu setiap peserta didik harus mempunyai motivasi di dalam dirinya untuk mengikuti proses pembelajaran.

Pendidikan jasmani dibedakan dengan olahraga. Dalam arti sempit olahraga diidentikkan sebagai gerak badan. Olahraga berasal dari kata "olah" berarti melatih diri dan "raga" berarti badan. Secara luas olahraga diartikan segala kegiatan atau usaha untuk mendorong, membangkitkan, mengembangkan, dan membina kekuatan-kekuatan jasmaniah maupun rokhaniah pada setiap manusia (Rohman, 2016). Pendidikan jasmani, olahraga dan kesehatan (PJOK) merupakan pendidikan yang menjadikan aktivitas jasmani sebagai media untuk mencapai perkembangan individu secara menyeluruh. Pendidikan jasmani, olahraga dan kesehatan sebagai wadah penyempurnaan kepribadian dan sarana pengembangan sikap, kepribadian, dan perilaku meletakan landasan nilai moral yang kuat melalui nilai-nilai yang dikandungnya seperti sportivitas, kejujuran, kedisiplinan, bertanggung jawab, kerjasama, percaya diri, dan demokratis (Surahni, 2017; Paramitha \& Anggara, 2018) Tujuan pembelajaran PJOK Pendidikan jasmani dan olahraga kesehatan pada hakikatnya adalah proses pendidikan yang memanfaatkan aktivitas fisik olahraga untuk menghasilkan perubahan holistik dalam kualitas individu, baik dalam hal fisik, mental serta emosional.

Melalui pembelajaran online/daring membuat peserta didik kurang pengawasan dalam mengikuti proses belajar, sehingga tidak semua peserta didik mampu memahami materi yang disampaikan oleh guru dalam pembelajaran PJOK. Pembelajaran Pendidikan Jasmani Olahraga dan Kesehatan masih dipandang sebelah mata oleh guru lain (guru kelas) karena mata pelajaran ini dianggap hanya sebagai mata pelajaran selingan/pelengkap saja agar siswa tidak jenuh menerima pelajaran di kelas (Sartinah, 2008). Pembelajaran daring merupakan pembelajaran yang menggunakan jaringan internet dengan aksesibilitas, konektivitas, fleksibilitas, dan kemampuan untuk memunculkan berbagai jenis interaksi pembelajaran (Sadikin, Ali dan Hamidah, 2020). Sedangkan menurut (Sari et al., 2021) Pembelajaran daring atau online merupakan pembelajaran berdasarkan pada teknologi yang bahan belajarnya dikirim secara elektronik ke peserta didik dari jarak jauh dan menggunakan jaringan komputer. Sehingga dengan permasalahan tersebuat membuat peserta didik kesulitan dalam melakukan gerakan. Hal ini disebabkan karena kurangnya pengawasan dari guru dalam proses pembelajaran. Akibat adanya covid-19 peserta didik tidak bisa mengikuti pembelajaran di sekolah seperti biasa, dimana pembelajaran PJOK harus diberikan kepada peserta didik walaupun secara online. Disamping itu pembelajaran PJOK juga membantu peserta didik dalam melakukan aktivitas olahraga yang diharapkan membentuk imun tubuh agar semakin kuat sehingga dapat mencegah peserta didik untuk terinfeksi oleh virus corona.

Berdasarkan hasil observasi peneliti banyak peserta didik kelas XI SMK Triatmajaya Singaraja kesulitan untuk memahami pelajaran khususnya di dalam mata pelajaran PJOK, beberapa peserta didik menyampaikan keluhan yang membuatnya malas dan kurang termotivasi pada saat proses pempelajaran, dikarenakan proses pembelajaran daring tersebut kurang efektif bagi peserta didik, sehingga membuat motivasi peserta didik dalam mengikuti proses pembelajaran belum optimal. Mengingat tujuan PJOK adalah mengembangkan aspek kebugaran jasmani, keterampilan gerak, keterampilan berpikir kritis, keterampilan sosial, penalaran, stabilitas emosional, tindakan moral, aspek pola hidup sehat dan pengenalan lingkungan bersih melalui aktivitas jasmani, olahraga dan kesehatan terpilih yang dilaksanakan secara sistematis dalam rangka mencapai tujuan pendidikan nasional. Dengan demikian, mempersulit peserta didik dalam melakukan gerakan karena penerapan pembelajaran hanya melalui teori saja. Pada saat memberikan pembelajaran praktek secara online dapat menyulitkan peserta didik karena masih banyak gerakan yang memerlukan adanya pengelompokan, bimbingan serta arahan dari guru PJOK. 
Berdasarkan latar belakang di atas peneliti tertarik untuk melakukan penelitian dengan judul "Motivasi Mengikuti Pembelajaran PJOK Di Masa Pandemi Covid-19 Pada Peserta Didik Kelas XI SMK Triatmajaya Singaraja Tahun Pelajaran 2020/2021.

\section{Metode}

Penelitian ini merupakan penelitian deskriptif kuantitatif dengan jenis penelitian survey. Dimana dalam penelitian ini tidak ada perlakuan dari peneliti, melainkan langsung mengambil data dari sumbernya. Penelitian ini dirancang untuk mendeskripsikan dan menjelaskan tentang motivasi peserta didik dalam mengikuti pembelajaran PJOK pada masa pandemi covid-19. Populasi yang digunakan dalam penelitian ini adalah seluruh peserta didik kelas XI SMK Triatmajaya Singaraja,yang dibagi menjadi 8 kelas diantaranya XI P1, XI P2, XI P3, XI P4, XI K1, XI K2, XI K3, XI K4. Dalam penelitian ini pengambilan sampel menggunakan non random sampling yang dilakukan dengan cara Quota Sampling yang artinya pengambilan sampel dengan menetapkan subyek yang akan diteliti. Berdasarkan pendapat tersebut sampel dalam penelitian ini adalah $25 \%$ × $237=59$. Jumlah sampel inilah yang akan digunakan sebagai responden dalam penelitian ini yaitu sebanyak 59 peserta didik kelas XI SMK Triatmajaya Singaraja tahun pelajaran 2020/2021.

Pengumpulan data dalam penelitian ini adalah dengan penyebaran Kuisioner kepada sampel penelitian. Kuisioner adalah teknik pengumpulan data yang dilakukan dengan cara memberikan beberapa pertanyaan atau pernyataan tertulis kepada responden untuk kemudian dijawab oleh responden tersebut.

Pengumpulan data dilakukan menggunakan instrument penilaian berupa angket untuk mengetahui motivasi peserta didik kelas XI SMK Triatmajaya Singaraja dalam mengikuti pembelajaran PJOK pada masa pandemi covid-19. Penilaian berupa angket ini berisi bagian isi dan bagian alasan. Bagian pertama memuat respon peserta didik terhadap pilihan ganda angket yang disediakan yang berkaitan dengan konten, sedangkan bagian kedua menuntut peserta didik agar memberikan alasan terkait jawabannya pada bagian pertama. Angket yang akan digunakan dalam penelitian terdiri dari butir-butir pertanyaan terkait motivasi peserta didik dalam mengikuti pembelajaran PJOK yang termasuk ke dalam jenis kuisioner tertutup karena peneliti sudah menyediakan jawaban dalam kuisioner tersebut sehingga responden cukup memilih jawaban yang telah disediakan. Kuisioner diberikan kepada peserta didik kelas . Kuisioner ini menggunakan skala likert dengan 4 dimensi penilaian yaitu sangat setuju (SS), setuju (S), tidak setuju (TS), dan sangat tidak setuju (STS).

Tabel 1. Skala Penilaian atau Kataggori

\begin{tabular}{cccc}
\hline No & Kriteria & Rentangan & Katagori \\
\hline 1. & $\mathrm{Mi}+1.5 \mathrm{SDi}, \leq \mathrm{Mi}+3.0 \mathrm{SDi}$ & $65 \leq 80$ & Sangat Tinggi \\
2. & $\mathrm{Mi}+0,5 \mathrm{SDi} \leq \mathrm{Mi}+1,5 \mathrm{Sdi}$ & $55 \leq 65$ & Tinggi \\
3. & $\mathrm{Mi}-0,5 \mathrm{SDi} \leq \mathrm{Mi}+0,5 \mathrm{Sdi}$ & $45 \leq 55$ & Sedang \\
4. & $\mathrm{Mi}-1,5 \mathrm{SDi} \leq \mathrm{Mi}-0,5 \mathrm{Sdi}$ & $35 \leq 45$ & Rendah \\
5. & $\mathrm{Mi}-3.0 \mathrm{SDi} \leq \mathrm{Mi}-1.5 \mathrm{Sdi}$ & $20 \leq 35$ & Sangat Rendah \\
\hline
\end{tabular}

\section{Hasil dan Pembahasan}

\section{Hasil Penelitian}

Motivasi peserta didik kelas XI SMK Triatmajaya Singaraja dalam mengikuti pembelajaran PJOK pada masa pandemi covid-19 telah diukur menggunakan angket yang terdiri dari 20 butir pernyataan yang terssaji pada Tabel 2 . 
Tabel 2. Analisis Pernyataan

\begin{tabular}{|c|c|c|c|c|c|c|c|c|}
\hline \multirow{2}{*}{ No } & \multirow{2}{*}{ Pernyataan } & \multicolumn{4}{|c|}{ Tangapan responden } & \multirow{2}{*}{$\mathbf{N}$} & \multirow{2}{*}{$\begin{array}{l}\text { Rata- } \\
\text { Rata }\end{array}$} & \multirow{2}{*}{ Kategor } \\
\hline & & $\mathbf{S ~ T}$ & $\mathbf{S}$ & TS & STS & & & \\
\hline 1. & $\begin{array}{l}\text { Saya perlu belajar PJOK } \\
\text { pada masa pandemi covid- } \\
19 .\end{array}$ & 50 & 9 & 0 & 0 & 59 & 96.2 & $\begin{array}{l}\text { Sangat } \\
\text { Tinggi }\end{array}$ \\
\hline 2. & $\begin{array}{l}\text { Saya ingin belajar PJOK } \\
\text { dengan mudah dan cepat } \\
\text { memahami materi yang } \\
\text { diberikan. }\end{array}$ & 36 & 23 & 0 & 0 & 59 & 90.3 & $\begin{array}{l}\text { Sangat } \\
\text { Tinggi }\end{array}$ \\
\hline 3. & $\begin{array}{l}\text { Saya tertarik untuk } \\
\text { mendalami materi PJOK } \\
\text { yang diberikan oleh guru. }\end{array}$ & 28 & 31 & 0 & 0 & 59 & 86.9 & $\begin{array}{l}\text { Sangat } \\
\text { Tinggi }\end{array}$ \\
\hline 4. & $\begin{array}{l}\text { Saya tertarik untuk } \\
\text { melakukan aktivitas yang } \\
\text { terdapat pada materi PJOK } \\
\text { dengan mudah. }\end{array}$ & 36 & 23 & 0 & 0 & 59 & 84.7 & $\begin{array}{l}\text { Sangat } \\
\text { Tinggi }\end{array}$ \\
\hline 5 & $\begin{array}{l}\text { Saya tertarik } \\
\text { memperhatikan materi yang } \\
\text { dijelaskan oleh guru. }\end{array}$ & 20 & 39 & 0 & 0 & 59 & 83.5 & $\begin{array}{l}\text { Sangat } \\
\text { Tinggi }\end{array}$ \\
\hline 6. & $\begin{array}{l}\text { Materi PJOK yang } \\
\text { dijelaskan oleh guru sangat } \\
\text { menarik bagi saya. }\end{array}$ & 16 & 43 & 0 & 0 & 59 & 81.8 & $\begin{array}{l}\text { Sangat } \\
\text { Tinggi }\end{array}$ \\
\hline 7. & $\begin{array}{l}\text { Saya merasa senang dalam } \\
\text { pembelajaran PJOK. }\end{array}$ & 36 & 23 & 0 & 0 & 59 & 90.3 & $\begin{array}{l}\text { Sangat } \\
\text { Tinggi }\end{array}$ \\
\hline 8. & $\begin{array}{l}\text { Saya tidak nyaman dengan } \\
\text { pembelajaran PJOK. }\end{array}$ & 0 & 0 & 33 & 26 & 59 & 86.0 & $\begin{array}{l}\text { Sangat } \\
\text { Tinggi }\end{array}$ \\
\hline 9. & $\begin{array}{l}\text { Pembelajaran PJOK } \\
\text { merupakan aktivitas yang } \\
\text { membosankan. }\end{array}$ & 0 & 0 & 26 & 33 & 59 & 89.0 & $\begin{array}{l}\text { Sangat } \\
\text { Tinggi }\end{array}$ \\
\hline 10. & $\begin{array}{l}\text { Pembelajaran PJOK } \\
\text { memberikan hal yang positif } \\
\text { pada diri saya. }\end{array}$ & 41 & 17 & 0 & 1 & 59 & 92.8 & $\begin{array}{l}\text { Sangat } \\
\text { Tinggi }\end{array}$ \\
\hline 11. & $\begin{array}{l}\text { Saya mengikuti } \\
\text { pembelajaran PJOK dengan } \\
\text { sarana yang memadai. }\end{array}$ & 15 & 44 & 0 & 0 & 59 & 81.4 & $\begin{array}{l}\text { Sangat } \\
\text { Tinggi }\end{array}$ \\
\hline 12. & Sarana yang ada tidak & 5 & 4 & 39 & 11 & 59 & 72.5 & \\
\hline
\end{tabular}




\begin{tabular}{|c|c|c|c|c|c|c|c|c|}
\hline \multirow{2}{*}{ No } & \multirow{2}{*}{ Pernyataan } & \multicolumn{4}{|c|}{ Tangapan responden } & \multirow{2}{*}{$\mathbf{N}$} & \multirow{2}{*}{$\begin{array}{l}\text { Rata- } \\
\text { Rata }\end{array}$} & \multirow{2}{*}{ Kategor } \\
\hline & & $\mathbf{S ~ T}$ & $\mathbf{S}$ & TS & STS & & & \\
\hline & $\begin{array}{l}\text { membantu dengan baik } \\
\text { dalam melakukan } \\
\text { pembelajaran PJOK. }\end{array}$ & & & & & & & $\begin{array}{l}\text { Sangat } \\
\text { Tinggi }\end{array}$ \\
\hline 13. & $\begin{array}{l}\text { Pembelajaran PJOK } \\
\text { menggunakan sarana yang } \\
\text { mudah ditemukan. }\end{array}$ & 16 & 43 & 0 & 0 & 59 & 81.8 & $\begin{array}{l}\text { Sangat } \\
\text { Tinggi }\end{array}$ \\
\hline 14. & $\begin{array}{l}\text { Berbagai macam sarana } \\
\text { sangat membantu saya } \\
\text { melaksanakan aktivitas } \\
\text { PJOK. }\end{array}$ & 17 & 42 & 0 & 0 & 59 & 82.2 & $\begin{array}{l}\text { Sangat } \\
\text { Tinggi }\end{array}$ \\
\hline 15. & $\begin{array}{l}\text { Pembelajaran PJOK sangat } \\
\text { bermanfaat bagi aktivitas } \\
\text { sehari-hari. }\end{array}$ & 43 & 15 & 0 & 1 & 59 & $92 . .4$ & $\begin{array}{l}\text { Sangat } \\
\text { Tinggi }\end{array}$ \\
\hline 16. & $\begin{array}{l}\text { Gerakan PJOK sangat } \\
\text { mudah untuk dilakukan dan } \\
\text { efektif. }\end{array}$ & 17 & 42 & 0 & 0 & 59 & 82.2 & $\begin{array}{l}\text { Sangat } \\
\text { Tinggi }\end{array}$ \\
\hline 17. & $\begin{array}{l}\text { Orang tua mendukung saya } \\
\text { untuk mendalami } \\
\text { pembelajaran PJOK. }\end{array}$ & 29 & 30 & 0 & 0 & 59 & 87.3 & $\begin{array}{l}\text { Sangat } \\
\text { Tinggi }\end{array}$ \\
\hline 18. & $\begin{array}{l}\text { Jika kedua orang tua sedang } \\
\text { beraktifitas di luar rumah, } \\
\text { saya tidak akan mengikuti } \\
\text { pelajaran PJOK }\end{array}$ & 0 & 0 & 29 & 30 & 59 & 87.3 & $\begin{array}{l}\text { Sangat } \\
\text { Tinggi }\end{array}$ \\
\hline 19. & $\begin{array}{l}\text { Banyaknya aplikasi di } \\
\text { smartphone membuat saya } \\
\text { lebih leluasa melakukan } \\
\text { aktivitas gerak dalam materi } \\
\text { pembelajaran PJOK. }\end{array}$ & 19 & 39 & 1 & 0 & 59 & 83.5 & $\begin{array}{l}\text { Sangat } \\
\text { Tinggi }\end{array}$ \\
\hline 20. & $\begin{array}{l}\text { Saya lebih mudah } \\
\text { memahami materi PJOK } \\
\text { dengan menggunakan } \\
\text { beberapa aplikasi yang ada } \\
\text { di smartphone. }\end{array}$ & 33 & 23 & 0 & 3 & 59 & 85.6 & $\begin{array}{l}\text { Sangat } \\
\text { Tinggi }\end{array}$ \\
\hline
\end{tabular}

Berdasarkan Tabel 3 di atas, dari hasil analisis 10 pernyataan motivasi intrinsik bila dirata-ratakan memperoleh rata-rata 88.1 bila dikonversikan pada tabel skala penilaian motivasi intrinsik dalam kategori sangat tinggi. Sedangkan hasil analisis 10 pernyataan motivasi ekstrinsik bila dirata-ratakan memperoleh rata-rata 83.6 bila dikonversikan pada 
tabel skala penilaian motivasi ekstrinsik dalam kategori sangat tinggi. Berdasarkan rata-rata yang diperoleh pada setiap komponen indikator motivasi yang dibagi menjadi indikator motivasi intrinsik dan indikator motivasi ekstrintik dari 59 orang diperoleh rata-rata 83.6, bila dikonversikan ke dalam tabel skala penilaian berapa pada kategori sangat tinggi.

\section{Simpulan}

Berdasarkan hasil penelitian yang diperoleh dalam penelitian ini yaitu peserta didik kelas XI SMK Triatmajaya Singaraja memiliki motivasi intrinsik dan ekstrinsik dalam pembelajaran PJOK pada masa pandemi covid-19 yang digolongkan dalam kategori sangat tinggi berdasarkan skala penilaian. Berdasarkan kesimpulan penelitian di atas, adapun saran yang dapat diberikan adalah sebagai berikut : 1) Kepada peserta didik diharapkan agar meningkatkan motivasi dalam pembelajaran PJOK pada masa pandemi covid-19 sehingga dapat menjaga kesehatan diri dan mencegah penularan covid-19 dengan meningkatkan daya tahan tubuh melalui aktivitas PJOK, 2) Kepada guru yang melaksanakan pembelajaran daring, agar selalu mengingatkan dan memotivasi peserta didik agar tetap menjaga kesehatan melalui aktivitas jasmani di tengah masa pandemi covid-19 ini, dan 3) Kepada peneliti lain yang berminat mengadakan penelitian deskriptif kuantitatif tentang survei motivasi peserta didik dalam pembelajaran PJOK pada masa pandemi covid-19 menjadikan hasil penelitian ini sebagai salah satu referensi untuk meneliti dalam lingkup yang lebih luas, sehingga diperoleh sumbangan ilmu yang lebih baik dan sesuai dengan perkembangan zaman dan diperoleh dalam penelitian lebih objektif.

\section{Daftar Pustaka}

Asyafah, A. (2019). Menimbang Model Pembelajaran (Kajian Teoretis-Kritis atas Model Pembelajaran dalam Pendidikan Islam). TARBAWY: Indonesian Journal of Islamic Education, 6(1), 19-32. https://doi.org/10.17509/t.v6i1.20569

Dimyati dan Mudjiono. (2006). Belajar dan Pembelajaran. Pt Rineka Cipta.

Djaali. (2007). Psikologi Pendidikan. PT Bumi Aksara.

Gunarsa, S. (2008). Psikologi Olahraga Prestasi. PT BPK Gunung Mulia.

Handarini, O. I., \& Wulandari, S. S. (2020). Pembelajaran Daring Sebagai Upaya Study From Home (SFH). Jurnal Pendidikan Administrasi Perkantoran (JPAP), 8(3), 465-503.

Hasibuan, M. S. P. (2010). Manajemen Sumber Daya Manusia. PT Bumi Aksara.

Lashley, Y. . (2014). Integrating computer technology intheteaching of Biology. 3(2).

Paramitha, S. T., \& Anggara, L. E. (2018). Revitalisasi Pendidikan Jasmani untuk Anak Usia Dini melalui Penerapan Model Bermain Edukatif Berbasis Alam. Jurnal Pendidikan Jasmani Dan Olahraga, 3(1), 41. https://doi.org/10.17509/jpjo.v3i1.10612

Pragholapati, A. (2020). "Covid-19 Impact on Students."

Rohman, U. (2016). Tinjauan Alternatif Konsep Model Pembelajaran Pendidikan Jasmani, Olahraga Dan Kesehatan (Pjok) Di Sekolah. Buana Pendidikan: Jurnal Fakultas Keguruan Dan Ilmu Pendidikan, 12(22), 111-118.

Sadikin, Ali dan Hamidah, A. (2020). "Pembelajaran Dairng di Tengah Wabah Covid-19". Universitas Jambi. 6(2).

Saifuddin, M. F. (2017). "E-learning dalam persepsi mahasiswa." Varia Pendidikan, 29(2), 103.

Sari, R. P., Tusyantari, N. B., \& Suswandari, M. (2021). Dampak Pembelajaran Daring Bagi Siswa Sekolah Dasar Selama Covid-19. Prima Magistra: Jurnal Ilmiah Kependidikan, 2(1), 9-15. https://doi.org/10.37478/jpm.v2i1.732

Sartinah, S. (2008). Peran Pendidikan Jasmani Olahraga Dan Kesehatan Dalam Perkembangan Gerak Dan Keterampilan Sosial Siswa Sekolah Dasar. Pendidikan 
Jasmani Indonesia, 5(2), 62-67.

Surahni. (2017). Pendidikan Jasmani, Olahraga dan Kesehatan (PJOK) sebagai Sarana Pendidikan Moral. The 6th University Research Colloquium 2017, 41-46.

Trianto. (2009). Mendesain Model Pembelajaran Invantif-Progresif. Kencana Prenada Group.

Wicaksono, P., Wibowo, U. L. N., \& ... (2021). Motivasi Belajar Taruna Pada Pembelajaran Online Sepanjang Pandemi COVID-19 (Sebuah Artikel Konseptual). Skyhawk ..., 1(1), 34-40. http://ejournal.icpa-banyuwangi.ac.id/index.php/skyhawk/article/view/7 